\title{
HAEMATOLOGICAL CHANGES DUE TO TRIATHLON COMPETITION
}

\author{
R. J. L. DAVIDSON, MD, FRCPE, FRCPath*, J. D. ROBERTSON, BSc, PhD* $†$ and R. J. MAUGHAN, BSc, PhDt \\ *Haematology Unit and tDepartment of Environmental and Occupational Medicine, University of Aberdeen Medical School, \\ Foresterhill, Aberdeen
}

\section{ABSTRACT}

A twelve parameter blood cell profile has been measured in 6 subjects before and after each phase of a triathlon event. This involved 29 miles cycling, 12 miles running and finally 18.5 miles canoeing.

There was a significant decrease in plasma volume $(8.7 \% \pm 3.1 \%, p<0.001)$ following the first phase (cycling); this decrease was sustained to the end of the event. A substantial increase in the number of circulating leukocytes after cycling (84 $\pm 58 \%)$ and running (255 $\pm 83 \%$ of pre-event value) was observed. There was no further leucocyte increment after the canoeing stage which may indicate that the circulating concentration of these cells was maximal after running. Fluid shifts following the postural alteration accompanying the different types of exercise and subject variability may have masked any subtle changes in the red cell parameters.

Key words: Peripheral blood profile, Triathlon

\section{INTRODUCTION}

The triathlon not only provides the opportunity to study the haematological changes induced by physical endurance but also, uniquely and simultaneously, the possible influence of several variables including the type, severity, duration and posture of the athletic activity.

Studies of peripheral blood changes induced by exercise have largely featured three main areas: firstly, changes in red cell number (RBC) and their haemoglobin content $(\mathrm{Hb})$ in relation to the oxygen carrying capacity of the blood (Shappell et al, 1971) and 'sports anaemia', a much researched topic (Hallberg and Magnusson, 1984; Dressendorfer et al, 1981; Cason et al, 1985); secondly, mobilisation and release of leukocytes (Hedfors et al, 1978; Moorthy and Zimmerman, 1978) and platelets (Warlow and Ogston, 1974; Davis et al, 1976) into the circulation in response to stress or tissue, including muscle damage; thirdly, plasma volume changes which have been demonstrated in both high intensity exercise (Rotstein et al, 1982) and endurance events (Dill and Costill, 1974; Maughan et al, 1985) and which modify all peripheral blood measurements.

This work describes the changes in the peripheral blood indices (Coulter profile), and plasma volume after each stage of a triathlon event. The changes in creatine kinase and lactate dehydrogenase isoenzyme profiles in response to the same event have been reported elsewhere (Maughan and Whiting, 1986).

\section{MATERIALS AND METHODS}

Blood samples were collected from 6 subjects participating in a triathlon event held on or by the banks of the River Dee, Aberdeenshire. The first phase consisted of cycling for 29 miles $(46.8 \mathrm{~km})$, the second of running 12 miles $(19.4 \mathrm{~km})$ and finally canoeing for 18.5 miles $(29.8 \mathrm{~km})$. The race was held in early October under cold $\left(4-10^{\circ} \mathrm{C}\right)$, wet conditions. The mean subject age was $33 \pm 11$ years (mean \pm SD) and mean weekly training over the previous 6 months had

Address for correspondence:

Dr. R. J. L. Davidson

Haematology Unit

Medical School

Foresterhill

Aberdeen AB9 2ZD involved $24 \pm 8$ miles running, $61 \pm 44$ miles cycling and 13 \pm 7 miles canoeing. Fluid was available ad libitum during the race and estimated as $1300 \pm 600 \mathrm{ml}$ by the subjects. Blood samples were taken before and after each stage of the race in the sitting position from an antecubital vein. Body weight was measured immediately after each sampling. One aliquot $(4 \mathrm{ml})$ of blood was dispensed immediately after collection into a tube containing $K_{2}$ EDTA (1.0 $\mathrm{mg}^{\mathrm{ml}} \mathrm{ml}^{-1}$ ) as anticoagulant. The remaining blood $(6 \mathrm{ml})$ was allowed to clot in a plain glass tube; the serum was collected after centrifugation and stored at $-20^{\circ} \mathrm{C}$. Total protein and serum albumin were estimated using a SMAC autoanalyser (Technicon Ltd., Basingstoke, UK).

Haematological analysis consisting of a 12 parameter profile was performed using a Coulter Counter S Plus I calibrated with $4 \mathrm{C}+$ (Coulter Electronics Ltd., London, UK). Differential counting of white cells $(200$ cells $)$ was undertaken by an experienced microscopist on Romanowsky stained blood films and the absolute cell numbers calculated. Reference values for these 12 blood parameters are shown in Table $\mathrm{I}$.

TABLE I

Reference values for twelve peripheral blood parameters from Davidson et al (1986). Mean \pm SD
Red blood cells (RBC)

Haemoglobin $(\mathrm{Hb})$

Packed cell volume (PCV)

Mean cell volume (MCV)

Mean cell haemoglobin ( $\mathrm{MCH}$ )

Mean cell haemoglobin concentration (MCHC)

Red cell distribution width (RDW)

Platelets (PLT)

Plateletcrit (Pct)

Platelet distribution width (PDW)

Mean platelet volume (MPV)

White cell count (WBC)

Neutrophils

Lymphocytes

Monocytes

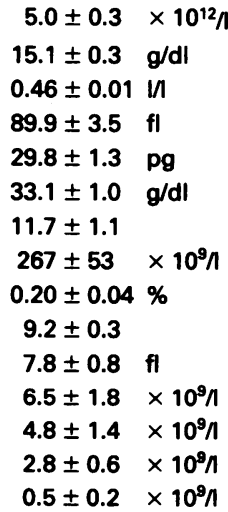

$5.0 \pm 0.3 \times 10^{12}$

$15.1 \pm 0.3 \mathrm{~g} / \mathrm{dl}$

$0.46 \pm 0.01 \mathrm{in}$

$89.9 \pm 3.5 \mathrm{fl}$

$29.8 \pm 1.3 \mathrm{pg}$

$33.1 \pm 1.0 \mathrm{~g} / \mathrm{dl}$

$11.7 \pm 1.1$

$267 \pm 53 \times 10^{9} n$

$0.20 \pm 0.04 \%$

$9.2 \pm 0.3$

$7.8 \pm 0.8$ fl

$6.5 \pm 1.8 \times 10^{9} n$

$4.8 \pm 1.4 \times 10^{9} n$

$2.8 \pm 0.6 \times 10^{9} n$

$0.5 \pm 0.2 \times 10^{9} 1$

The changes in plasma, whole blood and red cel volumes were calculated according to the method of Dill and Costill (1974) using circulating $\mathrm{Hb}$ concentration and PCV. 
The measurements in the post-exercise samples were compared with the pre-race values using analysis of variance followed by Student's t-test. Significance was assumed when $\mathrm{p}<0.05$.

\section{RESULTS}

Completion time for the triathlon was $6 \mathrm{~h} 27 \mathrm{~min} \pm 36 \mathrm{~min}$ with the cycling stage taking $85 \pm 8$ min, running $108 \pm$ $23 \mathrm{~min}$ and canoeing $173 \pm 16 \mathrm{~min}$. The overall times included $6 \pm 3 \mathrm{~min}$ and $14 \pm 2 \mathrm{~min}$ at the first and second switches between events.

\section{Pre-race values}

All 6 subjects showed a normal peripheral blood profile before the race apart from one who had a small but significant elevation of his platelet count $\left(459 \times 10^{9} \mid-1\right)$.

\section{Post-cycling values}

After the cycling stage (29 miles) significant ( $p<0.01$ ) increases in the mean values for $\mathrm{Hb}$ and PCV were demonstrated (Table II) corresponding to a reduction of plasma volume equivalent to $8.7 \pm 3.1 \%$ ( $p<0.001)$. This change per se could not account for the substantial increase $(84 \pm 58 \%)$ in circulating leukocytes, which was predominantly due to neutrophilia. Three subjects showed a small increase and 3 a small decrease in the absolute number of lymphocytes. All subjects showed a small increase in platelet count with the mean increase attaining statistical significance $(p<0.001)$.

\section{TABLE ॥}

Peripheral blood indices, mean \pm SD of 6 subjects, before the triathlon and after each of the 3 stages. For abbreviations and reference values see Materials and Methods.

\begin{tabular}{|c|c|c|c|c|}
\hline & Pre-race & $\begin{array}{l}\text { Post } \\
\text { Cycling }\end{array}$ & $\begin{array}{c}\text { Post } \\
\text { Running }\end{array}$ & $\begin{array}{c}\text { Post } \\
\text { Canoeing }\end{array}$ \\
\hline $\operatorname{RBC}\left(10^{12} /\right)$ & $5.0 \pm 0.3$ & $5.2 \pm 0.4$ & $5.0 \pm 0.4$ & $5.2 \pm 0.4$ \\
\hline $\mathrm{Hb}(\mathrm{g} / \mathrm{d} l)$ & $15.2 \pm 0.8$ & $16.1 \pm 1.1^{* *}$ & $15.6 \pm 1.4$ & $15.8 \pm 1.0$ \\
\hline $\operatorname{PCV}(1 / 1)$ & $0.45 \pm 0.02$ & $0.47 \pm 0.02^{* *}$ & $0.46 \pm 0.03$ & $0.47 \pm 0.03^{*}$ \\
\hline $\operatorname{MCV}(f)$ & $89.5 \pm 2.5$ & $90.0 \pm 2.7$ & $91.2^{*} \pm 2.5$ & $90.8 \pm 2.6^{*}$ \\
\hline $\mathrm{MCH}$ (pg) & $30.3 \pm 0.8$ & $31.0 \pm 0.6$ & $31.2 \pm 0.4$ & $30.7 \pm 0.8$ \\
\hline$M C H C$ (g/dl) & $34.0 \pm 0.0$ & $34.0 \pm 0.4$ & $34.2 \pm 0.4$ & $34.0 \pm 0.0$ \\
\hline RDW & $10.7 \pm 0.8$ & $11.0 \pm 1.3$ & $11.5 \pm 1.2$ & $11.8 \pm 0.8^{*}$ \\
\hline PLT (109/) & $300 \pm 88$ & $332 \pm 81^{\cdots *}$ & $338 \pm 85^{* * *}$ & $328 \pm 65$ \\
\hline $\operatorname{Pct}(\%)$ & $0.33 \pm 0.08$ & $0.38 \pm 0.10^{\ldots *}$ & $0.38 \pm 0.10^{* * *}$ & $0.35 \pm 0.07^{* *}$ \\
\hline MPV (fl) & $11.0 \pm 1.5$ & $11.4 \pm 1.4$ & $11.3 \pm 1.6$ & $10.5 \pm 1.3$ \\
\hline PDW & $10.5 \pm 0.5$ & $10.3 \pm 0.3$ & $10.4 \pm 0.4$ & $10.1 \pm 0.4$ \\
\hline WBC (× 109/1) & $5.6 \pm 1.1$ & $10.1 \pm 3.0^{\cdots *}$ & $18.6 \pm 5.5^{* *}$ & $18.1 \pm 3.2^{* * *}$ \\
\hline Neut. $\left(\times 10^{9} /\right)$ & $3.0 \pm 0.6$ & $7.6 \pm 3.0^{* * *}$ & $14.7 \pm 5.4^{* * *}$ & $16.0 \pm 3.1^{\cdots *}$ \\
\hline Eosino $\left(\times 10^{9} / 1\right)$ & $0.1 \pm 0.1$ & $0.0 \pm 0.1^{*}$ & $0.1 \pm 0.1$ & $0.0 \pm 0.0^{* * *}$ \\
\hline Baso $\left(\times 10^{9} / 1\right)$ & $0.1 \pm 0.1$ & $0.1 \pm 0.1$ & $0.3 \pm 0.2$ & $0.1 \pm 0.2$ \\
\hline Lymph $\left(\times 10^{9} / 1\right)$ & $2.2 \pm 0.5$ & $2.2 \pm 0.6$ & $2.7 \pm 0.6$ & $1.6 \pm 0.9$ \\
\hline Mono (× 109/1) & $0.3 \pm 0.2$ & $0.2 \pm 0.2$ & $1.0 \pm 0.5^{* *}$ & $0.5 \pm 0.4$ \\
\hline
\end{tabular}

Levels of significance: ${ }^{*} p<0.05, "{ }^{*} p<0.01,{ }^{\cdots *} p<0.001$

\section{Post-running values}

After the running stage (12 miles), the mean $\mathrm{Hb}$ and PCV values were found to have fallen to levels which were no longer significantly increased above the baseline values recorded before the race. Indeed, in 2 subjects, they were actually lower than these levels.

The total WBC had increased further, now $255.1 \pm 82.5 \%$ (range 184.6-371.1\%) above the pre-race and $93.2 \pm 56.5 \%$ (range $2.6-150.5 \%$ ) above the post-cycling values. In addition to the neutrophilia all the subjects now showed a significant monocytosis. Three subjects showed a small increase in lymphocyte numbers.

The platelet number also was elevated further $(14.5 \pm$ $9.7 \%$ above the pre-race value).

\section{Post-canoeing values}

After the canoeing stage (18.5 miles), the mean values for $\mathrm{Hb}$ and $\mathrm{PCV}$ remained essentially unchanged.

The total WBC had not altered significantly following canoeing although 3 subjects showed a slight fall in white cell number from that recorded on completion of the running stage. The monocyte increase noted after running was not sustained but eosinopenia was now evident with no eosinophils being identified in the 200 white cells classified in each blood film.

Similarly, while all subjects showed a peak rise in the platelet count following the running stage, $5 / 6$ subjects now showed a slight fall after canoeing although the count remained significantly higher than that recorded on the prerace (resting) sample.

\section{Plasma volume changes}

The $\mathrm{Hb}$ concentration and PCV were used to calculate plasma volume changes (Table III). The most significant plasma volume change occurred following the first event (cycling), in the form of a mean decrease $(8.7 \% \pm 3.1 \%$, $p<0.001$ ) which was sustained after running, (mean $=$ $6.2 \% \pm 7.2, \mathrm{NS}$ ) and canoeing, (mean $7.2 \pm 6.8, \mathrm{p}<0.05$ ). There was a similar reduction in the calculated value of total blood volume although this only attained statistical significance after the cycling stage. The concentrations of total serum protein and serum albumin were increased commensurate with the decrease in plasma volume. If this increase in total serum protein concentration had been solely attributable to a shift in cell water then the plasma volume would have been reduced by $13.4 \%$ post-cycling, $15.9 \%$ post-running and $8.5 \%$ post-canoeing when compared with the pre-race value. Similarly, if based on the albumin increase the corresponding values would have been $15.4 \%, 19.2 \%$ and $11.5 \%$. Throughout, there was no significant change in total body weight (Table III).

\section{TABLE III}

Changes in plasma, and red cell total blood volumes after each stage of a triathlon. The volumes are expressed as a percentage of the pre-race blood volume (Dill and Costill, 1974)

\begin{tabular}{lcccc}
\hline & Pre-race & $\begin{array}{c}\text { Post } \\
\text { Cycling }\end{array}$ & $\begin{array}{c}\text { Post } \\
\text { Running }\end{array}$ & $\begin{array}{c}\text { Post } \\
\text { Canoeing }\end{array}$ \\
\hline $\begin{array}{c}\text { Plasma volume } \\
(\%)\end{array}$ & $55.0 \pm 2.3$ & $50.3 \pm 3.2^{* *}$ & $52.2 \pm 5.2$ & $52.0 \pm 4.2^{*}$ \\
$\begin{array}{c}\text { Red cell } \\
\text { volume (\%) }\end{array}$ & $45.0 \pm 2.3$ & $44.2 \pm 1.9$ & $44.3 \pm 1.7$ & $45.2 \pm 2.8$ \\
$\begin{array}{c}\text { Total blood } \\
\text { volume (\%) }\end{array}$ & 100 & $94.5 \pm 2.1^{* * *}$ & $96.5 \pm 4.2$ & $96.2 \pm 3.9$ \\
$\begin{array}{c}\text { Serum Protein } \\
\text { (g/l) }\end{array}$ & $82 \pm 4$ & $93 \pm 7^{* *}$ & $95 \pm 9^{* *}$ & $89 \pm 8^{*}$ \\
$\begin{array}{c}\text { Serum albumin } \\
\text { (g/l) }\end{array}$ & $52 \pm 3$ & $60 \pm 3^{* * *}$ & $62 \pm 4^{* * *}$ & $58 \pm 3^{* * *}$ \\
$\begin{array}{c}\text { Body weight } \\
\text { (kg) }\end{array}$ & $68.4 \pm 8.0$ & $68.2 \pm 8.0$ & $67.6 \pm 8.0$ & $67.8 \pm 8.1$ \\
\hline
\end{tabular}

Levels of significance: ${ }^{*} p<0.05,{ }^{*} p<0.01, \cdots p<0.001$ 


\section{DISCUSSION}

The interpretation and significance of alterations in the number and concentration of the cellular constituents of peripheral blood following exercise must take account of any simultaneous change in plasma distribution or volume.

In this study, the reduction in plasma volume calculated from the haematological parameters was found to be lower $(7-8 \%)$ than that based on total serum protein $(9-15 \%)$ or serum albumin $(12-19 \%)$ concentrations. Previous studies have shown a similar discrepancy between these differently computed values in marathon running (Maughan et al, 1985) where it may reflect release of cellular protein into the circulation. The shift in plasma volume appeared to be maximal at the end of the first stage (cycling) but its subsequent maintenance throughout the remainder of the event may have been due to the availability of fluid ad libitum to the participants. The reduction in plasma volume did not appear to be due to total fluid loss, as body weight did not change significantly during the exercise and may therefore have been at least partially related to a redistribution of plasma and/or cellular components. The changes in plasma volume seen after exercise may be determined not only by the type of exercise.

The changes in plasma volume seen after exercise may be determined not only by the type of exercise, but also by such factors as intensity and posture and the state of preexercise hydration of the participant. The mechanism of the fluid shifts which occur during running and cycling may be quite different even though both activities predominantly involve leg muscle movements in an upright stance (Senay et al, 1980). Further, Hagan et al (1978) have indicated that any such differences attributed to the degree and type of exercise may be more simply explained on the basis of rapid plasma volume changes accompanying postural alteration. A reduction in plasma volume during the canoe stage was expected because of the subjects assuming a sedentary position, but this anticipated change did not occur. One must bear in mind, however, that this prediction did not take into account either the fall in plasma volume established in the two earlier exercise phases or the influence of both leg and arm involvement during canoeing.

The substantial increases in circulating neutrophils following both running and cycling cannot be attributed to changes in plasma volume. The response has been previously recorded during and following endurance events (Moorthy and Zimmerman, 1978; Davidson et al, 1987) but interestingly, the final canoeing stage was not accompanied by an additional leukocyte increment. In fact the lymphocyte and monocyte number showed an absolute decrease. This observation may be related to the form and degree of physical activity with emphasis changing from leg to leg/arm muscle contraction. Our published observations indicate that circulating leukocytes may peak at 1-2 hours after the end of a 16 mile road race $(n=5)$ whereas after a marathon the highest leukocyte count is found immediately post exercise (Davidson et al, 1986). This time difference in leukocyte peaking may be related to the duration of the exercise and hence suggests that the leukocyte concentration was maximal after the running stage of the triathlon. The increases in platelet count are statistically significant but less dramatic than seen after marathon running (Davidson et al, 1987) and mirror the overall leukocyte changes.
The increases in platelet count are statistically significant but less dramatic than seen after marathon running (Davidson et al, 1986) and mirror the overall leukocyte changes.

Any slight changes in the red cell parameters are likely to have been masked by variability between individuals in this small group and by the plasma volume changes. No striking alterations in RBC, MCH or MCHC were recorded but small and statistically significant increases in MCV and RDW were recognised which, taken together, might indicate mobilisation and release of larger (younger) red cells during the protracted physical effort or subtle changes involving red cell deformability, water content or membrane structure (Galea and Davidson, 1985).

In conclusion, this field study has failed to demonstrate any clear-cut differences in the peripheral blood changes induced by the three different forms of athletic activity despite the variation in duration, posture and pattern of muscle involvement. The lack of such correlation may be attributed to the continuity and sequence of the activities, and their cumulative and interactive effects.

\section{ACKNOWLEDGEMENT}

This study was supported by grants from Shell (UK) Exploration and Production and The Health Promotion Research Trust.

\section{References}

Cason,

Davidson, R. J. L., Robertson, J. D., Galea, G. and Maughan, R. J., 1987 "Hematology of marathon running". Int.J.Sports Med. (in press).

Davis, G. L., Abildgaard, C. F., Bernauer, E. M. and Britton, M., 1976 "Fibrinolytic and hemostatic changes during and after maximal exercise in males". J.Appl.Physiol. 40: 287-292.

Dill, D. B. and Costill, D. L., 1974 "Calculation of percentage changes in volumes of blood, plasma and red cells in dehydration". J.Appl.Physiol. 37: 247-248.

Dressendorfer, R. H., Wade, C. E. and Amsterdam, E. A., 1981 "Development of pseudoanemia in marathon running during a 20-day road race". JAMA 246: $1215-1218$.

Galea, G. and Davidson, R. J. L., 1985 "Haemorheology of marathon running". Int.J.Sports Med. 6: 136-138.

Hagan, R. D., Diaz, F. J. and Horvath, S. M., 1978 "Plasma volume changes with movement to supine and standing positions". J.Appl.Physiol. 45: 414-418.

Hallberg, L. and Magnusson, B., 1984 "The aetiology of 'sports anaemia'. (Editorial). Acta Med.Scand. 216: 145-148.

Hedfors, E., Biberfeld, P. and Wahren, J., 1978 "Mobilisation to the blood of human non-T and $K$ lymphocytes during physical exercise". J.Clin.Lab.Immunol. 1: 159-162.

Maughan, R. J., Whiting, P. H. and Davidson, R. J. L., 1985 "Estimation of plasma volume changes during marathon running". Brit.J.Sports Med. 19: 130-141.

Maughan, R. J. and Whiting, P. H., 1986 "Creatine kinase and lactate dehydrogenase isoenzyme profiles in response to triathlon competition. Exercise Physiology: Current Selected Research (Ed. C. O. Dotson and J. H. Humphrey). Volume 3. AMS Press, New York. In press.

Moorthy, A. V. and Zimmerman, S. W., 1978 "Human leukocyte response to an endurance race". Europ.J.Appl.Physiol. 38: 271-276.

Rotstein, A., Bar-Or, O. and Dlin, R., 1982 "Haemoglobin, hematocrit and calculated plasma volume changes induced by a short, supramaximal task". Int.J.Sports Med. 3: 230-233.

Senay, L. C., Rogers, G. and Jooste, P., 1980 "Changes in blood plasm during progressive treadmill and cycle exercise". J.Appl.Physiol. 49: $59-65$.

Shappell, S. D., Murray, J. A., Bellingham, A. J., Woodson, R. D., Detter, J. C. and Lenfant, C., 1971 "Adaptation to exercise: role of hemoglobin affinity for oxygen and 2,3 diphosphoglycerate". J.Appl.Physiol. 30: 827-832.

Warlow, C. p. and Ogston, D., 1974 "Effect of exercise on platelet count, adhesion and aggregation". Acta Haemat. 52: 47-52. 